\title{
ESTUDIOS
}

\section{El pensamiento musical de Pablo de Olavide y Jáuregui (1725-1803): perfiles inéditos de un peruano ilustrado}

\author{
The musical thought of Pablo de Olavide y Jáuregui \\ (1725-1803): the unknown profile \\ of an illustrated Peruvian
}

\author{
por \\ Javier Marín-López \\ Facultad de Humanidades y Ciencias de la Educación \\ Universidad de Jaén, España \\ marin@ujaen.es \\ Virginia Sánchez-López \\ Facultad de Humanidades y Ciencias de la Educación \\ Universidad de Jaén, España \\ vsanchez@ujaen.es
}

\begin{abstract}
El presente trabajo analiza por primera vez el importante papel que la música desempeñó en el proyecto personal y político del intelectual y escritor peruano Pablo de Olavide y Jáuregui (1725-1803). Partiendo de una revisión crítica de la bibliografía previa y de la información inédita contenida en el Archivo Histórico Nacional de Madrid, exploramos sus gustos y aficiones musicales, su interés por el teatro lírico, el desarrollo del modelo de tertulia con música a la que asistían melómanos ilustrados -él mismo era cantante e intérprete de teclado- y la proyección de su ideario musical en las colonias de las Nuevas Poblaciones de Andalucía y Sierra Morena, de las que fue impulsor y máximo dirigente entre 1767 y 1776 .
\end{abstract}

Palabras clave: Pablo de Olavide, pensamiento musical, tertulias privadas, Nuevas Poblaciones de Andalucía y Sierra Morena, Ilustración.

This article analyzes for the first time the important role that music played in in the personal y political project of the Peruvian intellectual and writer Pablo de Olavide y Jáuregui (1725-1803). Based on a critical review of the previous bibliography and the unpublished information contained in the National Historical Archive of Madrid, we explore Olavide's musical tastes and preferences, his interest in lyrical theater, his development of the model of soirée with music attended by illustrated music lovers -he himself was a singer and keyboard performer-and the projection of his musical ideology in the colonies of the Nuevas Poblaciones de Andalucia y Sierra Morena, of which he was promoter and leader between 1767 and 1776.

Keywords: Pablo de Olavide, musical thought, soirées, Nuevas Poblaciones de Andalucía y Sierra Morena, Enlightment.

Revista Musical Chilena, Año LXXIV, julio-diciembre, 2020, Nº 234, pp. 9-34 Fecha de recepción: 30-01-2019. Fecha de aceptación: 02-04-2019 
La vista con pinturas muy obscenas y con torpes canciones el oido, al dios del vientre con delicadas cenas deleitaban así cada sentido.

(copla cantada a Olavide tras su condena inquisitorial) ${ }^{1}$

\section{INTRODUCCIÓN²}

El 26 de febrero de 1803, Pablo de Olavide y Jáuregui (Lima, Perú, 1725 - Baeza, España, 1803) era enterrado cristianamente en la iglesia de San Pablo de Baeza (Jaén) en un solemne funeral con asistencia de clérigos de cinco conventos, el corregidor de la ciudad y la capilla de música de la catedral. El testamento del que fuera Superintendente de las Nuevas Poblaciones de Andalucía y Sierra Morena había prohibido de manera expresa que hubiese "música en los oficios funerales que se me hagan ni ningún otro aparato"3. Pero lo cierto es que, en contra de la voluntad del testador (entonces un anciano austero y arrepentido que quería acabar sus días con sencillez), el entierro se celebró con todo boato y contó con la presencia de los músicos de la seo baezana por expresa voluntad de su prima Tomasa de Arellano -su heredera universal y albacea-. Entre las obras interpretadas pudo haber secciones del Oficio y la Misa de difuntos del gran polifonista Cristóbal de Morales, copiadas en esos mismos años en un libro de polifonía de la catedral ${ }^{4}$. Aunque las obras de Morales estaban asociadas desde el mismo siglo XVI a las exequias reales, su interpretación en las ceremonias funerarias de una figura de Estado entonces rehabilitada, como era Olavide, resultaba particularmente apropiada.

Llevada a un plano más general, esta contradicción histórica entre la determinación testamentaria de Olavide y el desarrollo real de sus solemnes exequias se refleja en el principal aspecto que interesa a este trabajo: la presencia de la música en el proyecto personal y político del peruano, una faceta inédita de su poliédrica personalidad que, sorprendentemente, ha pasado inadvertida hasta ahora entre sus principales biógrafos, más centrados en el estudio de su pensamiento político-económico y su obra literaria como autor y traductor ${ }^{5}$.

1 Castañeda 1916: 107.

2 Este artículo es resultado de una investigación acerca de las prácticas musicales en Jaén y provincia financiada a lo largo de varios años por el Programa Operativo FEDER Andalucía 2014-2020, a través del Proyecto Sonido y ciudad: cartografías sonoras del Jaén contemporáneo (ss. XIX-XXI) [cód. 2921] y el Ministerio de Economía y Competitividad español, a través de dos Proyectos del Plan Nacional de I+D: Polifonía hispana y música de tradición oral en la era de las humanidades digitales [HAR2016-75371-P] y La música como interpretación en España: historia y recepción (1730-1930) [PID2019-105718GB-I00]. Ambos autores pertenecen al Grupo de Investigación "Música y Estudios Culturales" (HUM-942), de la Junta de Andalucía.

3 Baeza, Archivo Histórico Municipal de Baeza, sig. 3/15/466, citado por Rodríguez-Moñino 1994: 33 y 37. Con anterioridad, el testamento de Olavide había sido íntegramente publicado por Capel Margarito 1970: 237-240. En las citas de los documentos hemos desarrollado abreviaturas y normalizado la ortografía, la puntuación y el uso de mayúsculas.

4 El libro de polifonía 1, copiado a principios del siglo XIX (una obra está fechada en 1806), incluye varias obras para el Oficio y la Misa de difuntos; véase Marín-López 2007: 339-340.

5 Las monografías más relevantes acerca de Olavide son las de Lavalle 1885; Alcázar de Molina 1929; Defourneaux 1959/1965; Núñez 1987; Perdices Blas 1992; Capel Margarito 1997; y Marchena 2001. También se tratan distintas facetas del personaje en la nutrida bibliografía de las Nuevas Poblaciones de Andalucía y Sierra Morena, como Capel Margarito 1970 y Sánchez-Batalla Martínez 1998-2003, asî como las publicaciones derivadas de los diez congresos dedicados a las colonias carolinas hasta la fecha (las actas del último de ellos se editaron en 2018). 
Considerando lo anterior, el trabajo se divide en dos partes. La primera aborda la relación de Olavide con la música a lo largo de su vida, recorriendo las grandes etapas de su biografía, mientras que la segunda analiza la presencia y funciones de la música como parte de su proyecto político al frente de las Nuevas Poblaciones de Andalucía y Sierra Morena, la gran empresa repobladora de la Ilustración española. Ambas secciones ponen de manifiesto, por un lado, la trascendencia que la música tuvo en la trayectoria personal de Olavide y, por otro, la influencia directa de su pensamiento reformista en las prácticas musicales de las Nuevas Poblaciones durante los diez años en que ejerció como Superintendente del territorio foral. Para la realización de esta primera visión de conjunto acerca de la relación de Olavide con la música nos hemos basado en documentos inéditos de su época, en particular el extenso expediente inquisitorial formado a raíz de una denuncia de 1775 (citado por varios trabajos, pero nunca analizado desde el prisma musical) ${ }^{6}$, en datos publicados en diversos estudios y en sus propios escritos.

\section{LA MÚSICA EN EL PROYECTO PERSONAL DE OLAVIDE: HACIA UNA SEMBLANZA (EN TRES ACTOS)}

\section{Acto 1. Olavide en Lima: orígenes y primera formación (1725-1750)}

Los primeros indicios a propósito de la relación de Olavide con la música pueden colegirse de su etapa en Lima, ciudad que lo vio nacer en 1725 y en la que residió hasta 1750 . A principios del siglo XVIII, Lima era la ciudad más grande y poblada de América del Sur, pues como capital del virreinato del Perú se convirtió en un centro político, administrativo, comercial y también musical de primera importancia. El ritmo de la vida de la ciudad estaba determinado por la presencia del virrey, alter ego del rey, numerosos funcionarios y comerciantes, así como una tupida red de instituciones civiles y eclesiásticas que cultivaban la música y que incluía una catedral metropolitana, una universidad -la más antigua del continente, en la que nuestro protagonista se doctoró en teología y en derecho y ejerció su labor docente- y numerosos conventos, parroquias y cofradías, tanto de españoles como de indios, además de imprenta. Había también un coliseo que desarrollaba una intensa actividad teatral bajo el patronazgo de virreyes melómanos, quienes impulsaron la representación de óperas y zarzuelas, con frecuencia basadas en los argumentos mitológicos típicos del teatro áureo 7 . Olavide, destacado miembro de la jerarquía política de la ciudad (pues ejerció sucesivamente como abogado de Audiencia, asesor del Consulado y del Cabildo de

6 Aunque la denuncia generó un gran volumen de documentación conservada en distintos archivos (Perdices 1992: 348, nota 545), la fuente más importante se encuentra en Madrid, Archivo Histórico Nacional (AHN), Inquisición, 1866, exps. 1-10 (1768-1781), pues contiene las declaraciones de los ciento sesenta testigos oficiales (con doscientas cuarenta y cuatro acusaciones) y la correspondencia privada intercambiada entre Olavide y su círculo de confianza durante la preparación de la defensa, que fue interceptada por el Santo Oficio. Su consulta y vaciado íntegro se ha realizado a partir de la digitalización de Pares. Portal de Archivos Españoles (http://pares.mcu.es), que asciende a 5414 imágenes digitalizadas. Cuando el expediente no está foliado, remitimos al número de imagen digitalizada. Acerca de la gestión documental y los procedimientos burocráticos del Santo Oficio, véase Santiago Medina 2016.

7 De hecho, La Púrpura de la Rosa, considerada la primera ópera compuesta en América (con música de Tomás de Torrejón y Velasco sobre un libreto de Calderón), fue estrenada en Lima en 1701 para celebrar el decimoctavo cumpleaños de Felipe V y el primer aniversario de su proclamación; véase la edición de Stevenson 1976, que contiene un amplio estudio introductorio acerca de la música teatral en la ciudad. 
la ciudad y posteriormente oidor de la propia Audiencia), asistía a estas funciones que, al margen de preferencias personales, funcionaban como marcador de estatus en la estratificada sociedad virreinal (Capel Margarito 1997: 36-37). De hecho, y aunque hace años el peruanista Guillermo Lohmann Villena (1945: 404) desmontó el mito de que Olavide había impulsado la reconstrucción del teatro limeño tras el terremoto de 1746 (y que ello propició la apertura de un expediente por el Consejo de Indias) ${ }^{8}$, el coliseo de Lima permitió a Olavide su primer contacto con el mundo del teatro lírico, actividad de gran popularidad que -en consonancia con el ideario ilustrado- era vista como una oportunidad privilegiada de entretener y educar al pueblo llano, y por tanto se relacionaba con el buen gobierno.

Pero la música no solo era cultivada por las autoridades limeñas en la esfera pública. Se tiene constancia de que algunos virreyes disponían de capillas privadas de músicos en el palacio virreinal, en su mayoría de procedencia europea ${ }^{9}$. A imitación de los virreyes, la aristocracia criolla y otros miembros no titulados de la élite urbana imitaban sus hábitos culturales, entre los que figuraba la práctica de la música o la contratación de maestros en este arte. Ese pudo ser el caso de los Olavide: Pablo no perteneció a una familia noble ni parece que recibiese una educación musical formal -ni teórica ni práctica- en la Universidad de San Marcos, pero hay evidencias para sugerir que la música fue parte de la vida cotidiana de su familia. Así lo apunta el hecho de que en la tasación de los bienes de su hermana Josefa, tres años menor que Pablo y residente en Lima, había tres clavecines y un claviórgano, además de dos relojes con música (Vera 2018: 295 y 298) ${ }^{10}$. La procedencia francesa de algunos de estos instrumentos no debe sorprender, debido a que el patriarca, Martín, era uno de los más importantes comerciantes de la ciudad y había ejercido varios cargos públicos (y el propio Pablo se dedicaría a actividades comerciales) (Marchena 2001: 17). Esta noticia, además de probar la existencia de una intensa vida musical doméstica en el hogar de su hermana, permite especular con la posibilidad de que Pablo también pudiera adquirir su primera formación musical en su ciudad natal de manos de un maestro privado.

\section{Acto 2. Primera estancia de Olavide en España: Madrid, Sevilla, La Carolina y la condena inquisitorial (1752-1780)}

En 1752 Olavide emprendió viaje a España, pasando primero por Cádiz y luego por Sevilla. Instalado en Madrid, su matrimonio con la rica viuda Isabel de los Ríos (1755) y ciertas operaciones comerciales le permitieron ingresar como caballero en la todopoderosa Orden de Santiago (1756) y llevar una vida desahogada en la Corte. Desde allí planificó tres grandes viajes europeos, desarrollados entre 1757 y 1765: el primero por Francia, de año y medio (recorrió todas las provincias francesas, Saboya y Ginebra); el segundo por Italia, de unos quince meses (visitó Niza, Turín, Milán, Parma, Loreto, Roma, Nápoles, Florencia, Venecia y Padua, entre otros lugares); y el tercero a París, durante tres meses ${ }^{11}$. $\mathrm{Su}$ asistencia a teatros de ópera y reuniones aristocráticas en las grandes capitales musicales del momento le permitieron forjar un gusto musical ecléctico, vinculado a la estética

8 En realidad, las causas del proceso fueron diversas actividades fraudulentas, como la ocultación de la herencia de su padre y la falsificación de documentos notariales; véase Perdices Blas 2003: 14.

9 Un caso conocido es el de Manuel de Oms y Santa Pau, marqués de Castelldosríus y virrey entre 1707 y 1710, que disponía de una capilla privada integrada por nueve músicos; Stevenson 1976: 47 y 55. Para otros ejemplos de nobles músicos en la América colonial, véase Marín-López 2017.

10 Agradecemos al autor su amabilidad al compartirnos estas referencias antes de su publicación.

11 S.l., s.f., Madrid, Archivo Histórico Nacional (AHN), Inquisición, 1866, exp. 10, sin foliar (imagen digitalizada 231 de Pares). 
galante, donde cabían tanto la tragédie lyrique y los dramas neoclásicos franceses como la opera buffa napolitana, convertida en un idioma internacional paneuropeo con influencia en géneros nacionales como la opéra-comique francesa o la zarzuela española (Heartz 2003). En su casa de París, Olavide puso en marcha un salón que abría dos veces en semana y acogía a ilustres invitados, entre ellos el famoso tenor de ópera Pierre Jélyotte, descrito por su amigo el conde de Cheverny como le plus grand chanteur de l'Europe (Capel Margarito 1970: 246; y Crèvecoeur 1909, vol. 1: 98).

En síntesis, estos viajes permitieron al peruano entrar en contacto directo con la cultura de la Ilustración, adquirir novedades editoriales -era un lector empedernido, cultivado en variadas materias, recitador y un gran conversador- y conocer de primera mano a algunos de sus protagonistas como D'Alembert, Voltaire o Rousseau. Recordemos que este último había redactado en 1749 los artículos de música para la Encyclopédie, a petición de Diderot, y que posteriormente los ampliaría en su Dictionnaire de musique, publicado en 1767. Conociendo personalmente a los ideólogos de la Ilustración, y con algunos de los textos fundacionales del movimiento en su rica biblioteca ${ }^{12}$, no hay duda de que Olavide se impregnó de la concepción filosófica iluminista, que atribuía a la música cualidades positivas asociadas al buen gusto, a la razón y a su capacidad para expresar sentimientos, lo que hacía de ella una forma privilegiada de lenguaje ${ }^{13}$.

Aunque en este período madrileño Olavide estuvo alejado de la vida pública, su estancia en la Villa y Corte le permitió estrechar vínculos con el entorno cortesano y ganarse la confianza de personalidades que, con los años, acabarían ostentando una poderosa e influyente posición, como el conde de Aranda o Campomanes. Ambos políticos, junto con intelectuales como el poeta y músico Tomás de Iriarte (autor del célebre poema La Música $)^{14}$, asistían a las brillantes tertulias de signo renovador que Olavide organizaba con "mucho dispendio"15 en su residencia, siguiendo el modelo de las reuniones aristocráticas a las que había asistido en los salones franceses (Capel Margarito 1997: 110-111). Son años en los que el peruano vivió entregado al cultivo de las artes y la música, como ya señaló Defourneaux (1959: 79). Así lo confirma una de las cartas que Luis de Bejarano, conde de Villaseñor, envió a su tío Pedro Bravo de Lagunas, oidor de Lima, narrando la nueva vida disipada de Pablo en la capital del Imperio: "No haga vuestra merced juicio del proyecto de Olavide, que tiene en desvarío la cabeza, y porque me crea, le fío para que lo reserve en sí que tiene maestro de clave y canto" (Lavalle 1885: 32).

Otra de sus principales ocupaciones en Madrid fue la traducción y adaptación de obras neoclásicas francesas -que fueron representadas en los Reales Sitios y, posteriormente, en Sevilla-, y la composición de la zarzuela en un acto El celoso burlado, cuya autoría real ofrece dudas. Su atribución se basa en una anotación manuscrita que figura en uno de los ejemplares conservados del libreto impreso, pues la edición original, publicada por Joaquín Ibarra en 1764 , no señala autoría alguna ${ }^{16}$. No se ha localizado la música de esta zarzuela

12 Según indica Defourneaux 1959: 476-491, de la biblioteca privada de Olavide se conserva un inventario parcial de unos ochocientos cuarenta volúmenes correspondiente a cuatrocientos cincuenta títulos que resultaron sospechosos al Santo Oficio. Su biblioteca, por tanto, era mucho mayor: Perdices Blas 1992: 48, señala que en 1768 se recibieron en el puerto de Bilbao dos mil cuatrocientos volúmenes a su nombre.

13 Para una aproximación a la vida musical española desde la perspectiva del ideal ilustrado, sigue siendo válida la síntesis de Gallego 1988.

14 El poema se publicó por primera vez en 1779 y, debido a su fama, se reimprimió en numerosas ocasiones. Para una síntesis de su contenido, véase Martín Moreno 1985: 285-288, y Leza 2014: 107-111.

15 S.l., s.f., AHN, Inquisición, 1866, exp. 10, sin foliar (imagen digitalizada 232 de Pares).

16 Madrid, Universidad Complutense, Biblioteca Histórica, BH FLL 29265(3). 
(que por su texto se alinea en las nuevas tendencias de la zarzuela costumbrista basada en temas populares semejantes a los de la opera buffa), aunque se conocen los nombres de los actores cantantes que la interpretaron, supuestamente en su estreno del Teatro del Buen Retiro con motivo de la boda de la infanta Luisa y el gran duque de Toscana ${ }^{17}$. También se sabe que en 1793 el compositor Blas de Laserna puso música a esta historia, basándose entonces en un libreto de Luis Moclín ${ }^{18}$. Sí se ha conservado, en cambio, la tonadilla a tres voces El desertor compuesta en fecha desconocida (entre 1789 y 1801) por el músico Pablo del Moral, cuyo texto se basa en una obra homónima francesa traducida por Pablo de Olavide y posteriormente refundida por José López Sedano (Calderone 1987). Su argumento es premonitorio, pues encaja bien con el desgraciado perfil biográfico del limeño a partir de mediados de los años setenta: un joven y virtuoso militar del ejército francés es condenado a muerte por un delito del que es moralmente inocente, siendo al final perdonado por el rey ${ }^{19}$.

Desde el otoño de 1767 Olavide se instaló en Sevilla como Asistente o corregidor de la ciudad, Intendente del Ejército de Andalucía y Superintendente de las Nuevas Poblaciones. Entre Sevilla y la aldea de La Peñuela ${ }^{20}$ permaneció hasta noviembre de 1776, en que fue detenido y procesado por el Santo Oficio. En la ciudad hispalense, Olavide desplegó una intensa acción de gobierno y desarrolló un ambicioso plan de reformas que significó la modernización de dos importantes instituciones: la universidad y el teatro. En relación con la institución educativa, aprovechó la reciente expulsión de los jesuitas e ideó en 1768 un nuevo plan de estudios para la Universidad de Sevilla, pergeñado con un grupo de intelectuales sevillanos. Esta reforma aspiraba a superar el dogmatismo escolástico de las enseñanzas universitarias, hasta entonces en manos de clérigos y frailes, y a poner esta institución al servicio del Estado, como ocurría en las naciones modernas. Las nuevas enseñanzas no contemplaron la música, ni en su dimensión especulativa-como se impartía en la Universidad de Salamanca- ni tampoco en su vertiente práctica (Aguilar Piñal 1989). Ello se debía a que, en la mentalidad de Olavide, la universidad debía priorizar lo útil sobre lo agradable, y la enseñanza musical era una actividad más propia de academias e instituciones privadas, como las Sociedades Económicas de Amigos del País que comenzaron a fundarse en la década de 1770 a imagen de la Bascongada, de la que Olavide era socio honorario ${ }^{21}$.

Por lo que respecta al teatro, Olavide se mostró un firme defensor de su utilidad política y educativa, y antes de tomar posesión de su cargo en Sevilla impulsó la puesta en marcha de un teatro de ópera francesa en Cádiz, en cuya plantilla se incluían once actores, cinco cantantes y diecisiete bailarines (Aguilar Piñal 1974: 64). Ya en la ciudad hispalense, el peruano mandó construir un nuevo edificio en 1767 -previamente se habían solicitado al

17 La edición de Núñez 1971, anota el nombre de los actores José García, Eusebio Ribera, Diego Coronado, Teresa Segura y Joaquina Moro.

18 Madrid, Biblioteca Histórica Municipal (BHM), Mus 67-39.

19 BHM, Mus 128-10.

20 Convertida en ciudad, a propuesta de Olavide, en 1770 pasó a llamarse Real Carolina y se transformó en capital de las colonias.

21 Varios miembros de la Bascongada se dedicaban específicamente "a la música, sea instrumental o vocal, y a introducir el buen gusto, recogiendo lo más selecto que haya dentro y fuera de España y componiendo obras de su invención” (Bagüés Erriondo 1990: 108). Curiosamente, la Sociedad Patriótica Sevillana, cuyo acto inaugural se celebró en el Alcázar de Sevilla en presencia de Olavide, su primer presidente, no contempló las “academias de música” en sus estatutos de 1775, quizá porque ya se celebraban en la propia residencia del intendente, así como en otras residencias particulares; sí que incorporó, desde 1779, clases para la construcción de claves a cargo de Juan del Mármol (Calderón España 1991, vol. 2: 798-801). 
primer ministro de Parma planos del teatro de Bolonia o cualquier otro de Italia (Perdices Blas 1992: 35)- y lo dotó de un preciso reglamento para regular su funcionamiento y la propia formación de los actores de la compañía de José Chacón, en la que había numerosos cantantes italianos. Durante los siguientes doce años se interpretaron numerosísimas comedias y tragedias extranjeras, así como treinta y cinco óperas y zarzuelas, entre las que había no solo obras de los compositores napolitanos que dominaban la escena internacional (como Giovanni Paisiello, Niccolò Jommelli, Niccolò Piccini o Domenico Cimarosa), sino también las zarzuelas costumbristas de Fabián García Pacheco y Antonio Rodríguez de Hita, que contribuyeron de manera definitiva a la renovación del género en las décadas de 1760 y 1770 (Moreno Mengíbar 1998: 24-27). Como complemento de su plan de reforma teatral, Olavide publicó al año siguiente otro reglamento para instaurar en Sevilla los famosos bailes de máscaras durante el Carnaval. Estos espectáculos callejeros, tradicionalmente de carácter popular y burlesco, pasaban ahora a celebrarse en exclusiva dentro del teatro, adquiriendo una dimensión aristocrática que equiparaba a Sevilla con el refinamiento de las grandes capitales europeas, pues los únicos bailes autorizados, el minueto y la contradanza, eran ejecutados bajo la dirección de un maestro de baile (Aguilar Piñal 1974: 261-265).

Es probable que algunos de los músicos activos en Sevilla (ya fuera en el teatro o en otras instituciones) participasen en las tertulias que Olavide organizaba en el Real Alcázar de Sevilla, convertido en el nuevo centro de representación del poder del intendente en la capital andaluza. Allí hizo construir un pequeño teatro que acogía representaciones, y entre sus distinguidos asistentes figuraba un compatriota, José Barquíjano, quien pasó un año en Sevilla y llegó a ostentar el cargo de Consejero de Estado (lo que fue solemnemente celebrado en su Lima natal por medio de música) (Estenssoro 1989: 64-65). Según han señalado diversos estudios, en el contexto de esas tertulias se desarrollaba una vez por semana una "academia de música"22. En ella, grupos musicales de pequeñas dimensiones interpretaban lo más selecto de la música española, francesa e italiana del momento (breves arias y extractos de ópera y música instrumental de cámara), tanto para ser escuchada como bailada. Pero en algunas ocasiones se ejecutaban obras de mayor envergadura. Ese fue el caso de la zarzuela El hijo de Ulises, dedicada a Olavide, que se interpretó en la casa del teniente coronel Esteban de Liñán, y cuyo libreto se llevó a la imprenta por "no desagradarle [a Olavide] y merecer su distinguido voto" 23 . La obra se estructuraba en tres actos y cuarenta y una escenas, y el reparto incluía a cuatro personajes ${ }^{24}$. El impreso presenta un interesante prólogo en el que su autor, Antonio González de León, señala que la zarzuela fue un encargo y que debía representarse por un reducido número de personas (entre ellas la mujer del teniente coronel Liñán, Teresa Ignacio de Cárcamo), "poco acostumbradas a representar en público", por lo que "se quería mucha música". De hecho, las acotaciones del libreto muestran la existencia de numerosos coros cantados, recitados, arias y dúos, interpolados entre secciones habladas como es característico del género zarzuelístico. Pese a su importante extensión, este tipo de representaciones musicales formaban parte de un programa más amplio que servía no solo para debatir acerca de literatura, educación, economía y temas de actualidad, sino también para consolidar las redes sociales, proyectar un determinado estatus y, al mismo tiempo, servir de distracción a amigos y parientes.

22 Uno de los primeros fue Lohmann Villena 1964: 77. La noticia luego ha sido repetida, entre otros muchos, por Aguilar Piñal 1974: 78.

23 La función incluyó el sainete en dos partes El poeta cómico y se llevó a efecto a finales de 1767 o inicios de 1768, pues la licencia de imprenta está fechada los días 23 y 26 de febrero de 1768 (González de León 1768).

24 Estos eran Telémaco, hijo de Ulises; el príncipe griego Diomedes; la diosa Calipso y su ninfa Erotisa, acompañada de un coro de ninfas. 
Los biógrafos de Olavide han señalado su residencia más o menos permanente en La Carolina entre julio de 1769 y mayo de 1773, aunque sus viajes a Sevilla y las colonias eran constantes. Instalado en su nuevo palacio de La Peñuela, mandó construir un teatro y dio continuidad al modelo de tertulia cosmopolita e ilustrada ya comentado. No se tienen noticias concretas referidas al desarrollo de estas reuniones, pero a juzgar por sus experiencias previas en París, Madrid y Sevilla y de las propias prácticas de sociabilidad típicamente ilustradas, la música debió jugar un papel destacado. Esta nueva tertulia pronto se convirtió en parada obligada de muchas de las personalidades que viajaban desde la Villa y Corte de Madrid hacia Andalucía. Una de ellas fue nada menos que el VI conde de Fernán-Núnez, a quien Olavide había conocido en París; además de una Grandeza de España, el conde era un reputado melómano, autor de dos libros de música (Ejercicios para la composición y Ejercicios prácticos de armonía) y compositor de un Stabat Mater para dos sopranos y orquesta (1793) (Alonso Herreros 2013).

Entre los asistentes habituales a estas reuniones estaban los funcionarios del equipo ilustrado de Olavide: su subdelegado Miguel Ondeano, el contador Miguel Mínguez, el médico Juan Calvet, el ingeniero Carlos Lemaur, el cura José Estefani, el teniente Ramón Salas y el director de la fábrica de telas Rodolfo de León, entre otros ${ }^{25}$. También asistían dos de sus colaboradores más estrechos, ambos franceses, a quienes Olavide tenía en alta estima por su talento y honradez: su secretario personal, Bernardo Darquea (D'Arque), y el capellán Juan Lanes Duval, vicario eclesiástico de Sierra Morena. Darquea fue -como Olavide-, procesado por el Santo Oficio, encarcelado y luego desterrado a las Indias, hacia donde partió a principios de 177926. En una de las misivas que Darquea remitió a Duval por orden de Olavide y que fue interceptada por la Inquisición, se lamentaba de la desagradable situación provocada por la denuncia inquisitorial de fray Romualdo de Friburgo y recomendaba al vicario hacer música para calmar su espíritu: "Vuestra merced ejercítese en su flauta para tocar la música que me propongo tocar también en su compañía en desahogo de unos disgustos que ni vuestra merced ni nosotros merecemos"27.

De esta noticia, que por proceder de un documento privado ofrece toda credibilidad, se desprende que Lanes era flautista y que tanto él como Olavide practicaban música como pasatiempo. Aunque no se conozcan detalles adicionales, este tipo de noticias implican la existencia de instrumentos y repertorios musicales domésticos en La Carolina ${ }^{28}$. El mismo Darquea era igualmente músico. Durante su período como funcionario real en Ambato y Cochabamba (Audiencia de Quito) preparó para el obispo de Quito un plan para reorganizar la capilla de música de la catedral, y el viajero Alexander von Humboldt quedó asombrado por su genio y destreza musical y dancística: "Él declama, danza y toca magistralmente el violín. Ya por estos talentos solos podría brillar en Europa" (Moreno Yáñez y Borchart de Moreno 2005: 37).

Como ya ocurría en las tertulias madrileñas y sevillanas, algunos familiares estaban presentes, entre ellos Isabel de los Ríos, esposa de Olavide. Un síntoma de su interés por la música es la obra pía que ella instituyó en el colegio del Carmen de Baeza en honor del

25 Declaración de Bernardo Darquea, Madrid, 2 de mayo de 1776, AHN, Inquisición, 1866, exp. 3, fol. $1004 \mathrm{v}$.

26 Licencia de embarque de Bernardo Darquea, 28 de enero de 1779, Sevilla, Archivo General de Indias, Contratación, 5524, N.3, R.5.

27 Carta de Bernardo Darquea escrita por orden de Olavide a Duval, Madrid, 9 de mayo de 1776 , AHN, Inquisición, 1866, exp. 8, documento 16, fol. 48r.

28 Como ejemplo de colección de música en manos de un flautista amateur dedicado a la alta política, podría citarse el caso del militar venezolano Francisco Miranda; véase Calzavara 1987: 122 123 y 225-226. 
septenario de San José, que requería la participación de la capilla de música de la catedral baezana en los siete domingos anteriores a su festividad y en dos aniversarios (por su alma y la de su anterior marido, véase Capel Margarito 1970: 226-227). Otra asidua concurrente -de hecho, se dice que presidía las reuniones- era Gracia de Olavide, a quien el intendente presentaba como su prima o "media hermana". Diecinueve años mayor que ella, Pablo se ocupó de darle una cuidada formación en la que no faltó la música y la poesía. Instalada en Baeza junto con su marido Luis de Urbina, un militar amigo de su hermano, Gracia se mantuvo durante toda su vida muy vinculada a Pablo. Ello alimentó habladurías en torno a la relación entre ambos (se rumoreaba que no era su prima sino su amante), que fueron utilizadas con saña en contra del intendente, llegando al macabro esperpento de indicarse que, estando Gracia en su lecho de muerte, Olavide la instó a que cantase un juguete cómico al son de un violín ${ }^{29}$. Lo anterior, de ser cierto, acreditaría el valor que Olavide concedía a la música incluso en los momentos más trascendentes de la existencia humana, al tiempo que confirmaría la afición de Gracia por el canto, lo que poéticamente se menciona en la oda que Gaspar de Jovellanos -otro asiduo de las tertulias olavidianas- escribió a su muerte ${ }^{30}$.

\section{Acto 3 y cierre. El destierro francés y el regreso a Baeza (1780-1803)}

El 14 de noviembre de 1776 Olavide fue detenido en Madrid; vinieron después dos años en una cárcel secreta y el severo auto inquisitorial de 1778 con todo lo que implicó: destierro de la Corte, Sevilla, Lima y sus Nuevas Poblaciones, inhabilitación para cualquier cargo público para él y sus descendientes hasta la quinta generación, incautación de sus bienes y reclusión en un monasterio durante ocho años, entre otros aspectos recogidos en la sentencia (Sánchez-Batalla Martínez 1998-2003, vol. 2: 452). Un informe inquisitorial describe el viaje del peruano hacia un convento capuchino de Murcia en 1779 y relata cómo, durante una breve estancia en una posada de Almagro (Ciudad Real), un Olavide abatido y enfermo de gota seguía encontrando en la música un consuelo para sus desdichas. Según relataba el clérigo informante, "las diversiones que tiene el enunciado Olavide son acudir a su jardín, tocar el monacordio algún rato y cantar en lengua extranjera" ${ }^{1}$. En 1780 fue enviado a tomar unos baños medicinales en Caldas (Gerona), pero aprovechando la cercanía de la frontera huyó a París, donde instaló una nueva tertulia, ahora con el pseudónimo de Conde de Pilos, y se codeó con melómanos aristócratas como la condesa Du Barry, amante del rey Luis XV y tan aficionada a la música que se había hecho construir un pabellón de música en los jardines del castillo de Louveciennes, a las afueras de París (AA.VV. 1992: 173). En distintos lugares de Francia residió dieciocho años hasta que, en 1798, un indulto real le permitió regresar a España. Él, que había sido defensor de la Revolución Francesa, se sentía

29 El testimonio procede de un documento del expediente inquisitorial de Olavide, citado por Castañeda 1916: 101: "La muerte de esta mujer [Gracia] la refieren bien lastimosa. Estando en su última enfermedad y mandada sacramentar, respondió no era necesario, porque hacía pocos días había confesado. Agravóse, y el inicuo Pablo, en vez de prepararla como cristiana, le mandó se esforzara y, al son de un violín (!!), cantara un juguete, y con él se privó y murió”.

30 Jovellanos se refirió a ella como "La que atraía con su dulce canto / del aire vago a las canoras aves, / y los feroces brutos extraía / de sus cavernas; / cuyo sonoro penetrante acento / daba sentido a los peñascos duros, / y detenía en su corriente rauda / fuentes y ríos, / ¿dónde se ha ido? ¿Cómo no resuenan / en los amenos carolíneos valles / sus peregrinos melodiosos ecos / dulcisonantes?”; véase Caso González 1961: 114-115, "Oda primera en la muerte de doña Engracia Olavide", versos 33-44.

31 Carta de Juan González de Huelva al Tribunal del Santo Oficio de Toledo, Daimiel, 23 de febrero de 1780, AHN, Inquisición, 1866, exp. 10, sin foliar (imagen digitalizada 106 de Pares). 
entonces horrorizado por la violencia antirreligiosa que acarreó y, reconvertido, decidió instalarse en Baeza, donde habían fallecido su prima Gracia (1775) y su esposa Isabel (1783).

De estos años del exilio francés data la mayor parte de su producción literaria, que contiene algunas referencias a la música. Su obra más conocida fue El evangelio en triunfo o historia de un filósofo desengañado (1797-1798), una novela epistolar en cuatro volúmenes y unas mil setecientas páginas, en la que un incrédulo filósofo escribe a un amigo relatándole sus disputas con un fraile. Aunque constituye una apología de la religión católica, provocada por una crisis de conciencia, la obra permite entrever su ideario educativo, ilustrado pero católico, en particular en el cuarto volumen, aquel que contiene las ideas originales de Olavide (pues para los tres primeros se basó en una obra francesa) ${ }^{32}$. Así, en la carta XXXVI, donde aborda las disciplinas más valoradas para la formación de jóvenes agricultores, se menciona a la música entre las "artes agradables" junto con el dibujo: se trata de un arte "que en muchas ocasiones puede servirles de recreación inocente, y tal vez les será un desahogo necesario" ([Olavide] 1797-1798, vol. 4: 123). Este testimonio supone una cierta contradicción con el plan formativo que ideó para los colonos agrícolas de las Nuevas Poblaciones, que más adelante detallaremos.

La carta XXXVIII expone las funciones de una utópica Junta de Bien Público, encargada de gobernar el pueblo del filósofo. Entre los cometidos de esta Junta estaba la organización de unos premios en cada uno de los meses del año para fomentar las virtudes cristianas, la agricultura y las artes. La música juega aquí un papel importante como elemento articulador y solemnizador de la fiesta, pues está presente en el anuncio público del premio y acompaña al premiado y a su familia desde su casa a la iglesia y a su regreso ([Olavide] 1797-1798, vol. 4: 233-234). Aunque se trata de una ficción literaria, la presencia de la música en el entorno festivo y urbano de estos concursos no deja de recordar la participación musical en las celebraciones de las Reales Sociedades Económicas de Amigos del País, a las que Olavide era tan aficionado (Bagüés Erriondo 1990: 189-224; y Sanhuesa Fonseca 2013). De hecho, el peruano no solo formó parte, sino que impulsó de manera determinante la fundación de la Sociedad de Verdaderos Patricios de la Ciudad de Baeza y Reino de Jaén, lo que explica su temprana fundación (su sanción real, en mayo de 1774, la convierte en la segunda en antigüedad en toda España, por detrás de la Bascongada), y cuyos estatutos incluían el cultivo de la música junto con las ciencias y las artes "útiles" (Capel Margarito 1997: 18-19, y Jiménez Cavallé 1991: 132).

\section{EN EL "PUERTO DE LA FELICIDAD": LA MÚSICA EN EL PROYECTO POLÍTICO DE OLAVIDE}

¿De qué manera las documentadas inclinaciones musicales de Olavide se trasladaron a su proyecto político, las Nuevas Poblaciones de Sierra Morena, durante el proceso de instalación del régimen colonial? El extenso expediente generado a partir de la denuncia que el prefecto de los capuchinos alemanes afincados en Sierra Morena, fray Romualdo de Friburgo, hizo de Olavide ante la Inquisición en 1775 confirma que el intendente, haciendo uso de los plenos poderes que le concedía el Fuero, tuvo una injerencia directa en las prácticas musicales del "Puerto de la Felicidad", utópico y propagandístico nombre que se dio a las colonias carolinas para atraer colonos extranjeros. Aunque magnificadas e interpretadas desde un punto de vista dogmático y moralista (como es habitual en este

32 Algunas referencias musicales fueron censuradas, como aquella alusiva a la organización de un baile semanal en el pueblo del filósofo desengañado, presidido por el párroco; véase Dufour 1997: 10-11. 
tipo de fuentes, reflejo de tensiones ideológicas y procesos políticos mucho más complejos), las críticas del celoso capuchino y de otros testigos aportan reveladoras y detalladas informaciones acerca del peculiar paisaje sonoro que Olavide concibió para la sociedad rural idealizada de las Nuevas Poblaciones ${ }^{33}$.

Para comprender mejor la proyección del ideario de Olavide en las Nuevas Poblaciones y la centralidad de la música en su proyecto político, es imprescindible aproximarse brevemente a las singularidades con que fue concebida esta empresa colonizadora. El documento que regulaba los nuevos establecimientos y el plan de vida de los seis mil colonos alemanes, suizos y saboyanos principalmente (y también de los españoles allí establecidos, pues la colonización fue mixta con la idea de hacer prevalecer la lengua y costumbres españolas) era el comúnmente llamado Fuero de Población de Sierra Morena de 1767, redactado por Pedro Rodríguez de Campomanes, ministro de Hacienda, con la colaboración del propio Olavide y la supervisión de Miguel de Múzquiz, secretario de Hacienda y Guerra. En él no hay ninguna referencia a la música. Tan solo se indicaba, en su artículo 74, que todos los niños debían ir a la escuela a aprender primeras letras, lengua española y doctrina cristiana, labor que recaía en los sacristanes de las iglesias rurales. Es altamente probable que, siguiendo antiguas prácticas, la doctrina se enseñase cantándola para facilitar la memorización de los preceptos religiosos, aunque nada de ello se especifica en la documentación manejada (Marín-López 2018: 1517-1520).

Debido a que el proyecto consistía en una colonización agraria, no se instauraron estudios superiores, pues los moradores de esta nueva sociedad campesina estaban destinados a la labranza, a la cría de ganado y a las denominadas "artes mecánicas". La ausencia de una infraestructura musical institucionalizada imposibilitaba una práctica musical polifónica, lo que constituye una diferencia relevante con toda la legislación indiana relativa a la fundación de ciudades y la creación de instituciones eclesiásticas, recopilada en las Leyes de Indias y que Olavide, sin duda, conoció ${ }^{4}$. Ello se debió no a un desinterés del peruano por la música, sino sencillamente al marcado pragmatismo y utilitarismo que guio la empresa carolina y que, por otro lado, era inherente a la cultura ilustrada. Como prueba de lo anterior está el hecho de que la música, el baile y el aprendizaje de un instrumento musical, actividades propias de caballeros y servidores públicos, estaban contempladas en el plan de estudios que Olavide ideó para el Colegio de los Ingleses de Sevilla, que sí era de alta educación, al igual que en su proyecto de colegio sevillano para educar niñas nobles y ricas (Perdices Blas 1992: 294 y 296). Asimismo, el hecho de que los colonos fuesen ya católicos no hacía necesario implementar un programa integral de conversión religiosa basado en el empleo de la música, como desarrollaron en el Nuevo Mundo las órdenes religiosas que, por todo lado, tenían prohibido su establecimiento en las Nuevas Poblaciones por expreso deseo de Olavide.

De lo comentado se deduce que el perfil ideal de colono exigido al coronel bávaro Johann Kaspar von Thürriegel, encargado de reclutar voluntarios centroeuropeos en sus lugares de origen, era el de experimentados agricultores católicos, pues lo que se necesitaba era gente para trabajar la tierra. Sin embargo, a dos años de la publicación del Fuero, el mismo Olavide reconocía que, si bien algunos eran de familias honradas e inclinados al trabajo, había otros que no eran idóneos ni tenían experiencia previa en labores agrícolas, siendo la mayoría "tunos, vagos, desertores, músicos y mendigos que nunca han sabido

33 Las motivaciones ocultas de la denuncia a Olavide, que se convirtieron en uno de los grandes escándalos políticos de la Ilustración española, han sido desveladas por Gómez Urdáñez 2015.

34 Para una síntesis de algunos de los aspectos musicales contenidos en las Leyes de Indias, véase Andrés-Fernández 2017. 
nada y a quienes ha sido preciso forzar al trabajo" (Suárez Gallego 1988: s/n). Por tanto, se sabe que entre los primeros colonos había algunos músicos, aunque desconocemos sus nombres y ocupaciones específicas. Asimismo, las únicas plazas musicales oficiales instituidas en las iglesias de las Nuevas Poblaciones eran las de organista y sochantre, seleccionados y financiados por la Corona (en virtud del Real Patronato) y solo presentes en las iglesias mayores de La Carolina, capital de las colonias, y La Carlota (hoy provincia de Córdoba), donde había una subdelegación (Pérez Fernández 2016: 43). En este contexto de supuesta pobreza musical, el expediente inquisitorial contra Olavide permite no solo arrojar luz respecto de diversas prácticas musicales en las colonias carolinas, sino conocer detalles precisos de la implicación directa del peruano en su vida musical pública y privada, en particular acerca de la regulación de tres aspectos: el toque de las campanas, los cantos devocionales interpretados dentro de las iglesias, y los bailes públicos.

\section{La desacralización del espacio: los tañidos de las campanas}

Uno de los aspectos más controvertidos que Olavide legisló fue el uso de las diez campanas que quedaron instaladas en las nuevas iglesias de Sierra Morena ${ }^{35}$. Según fray Romualdo, el intendente "tiene prohibido que se toquen las campanas avisando a las misas que se celebran en los días festivos antes de la misa parroquial, ni en los funerales, ni contra las tempestades" 36 . La prohibición se hacía extensiva a otras prácticas litúrgicas y devocionales, como (1) el canto de Vísperas (aunque el médico Juan Calvet señaló que acompañó a Olavide y su prima Gracia "por la tribuna del coro a oír y cantar al mismo tiempo las Vísperas") ${ }^{37}$; (2) el rosario rezado o cantado los domingos por la tarde (práctica a su juicio ridícula y supersticiosa que causaba estafas en las limosnas); y (3) las rogativas o procesiones públicas de carácter penitencial celebradas de manera extraordinaria (para implorar buenas cosechas, el cese de tormentas o períodos de sequía y enfermedad). Por tanto, solo se anunciaban mediante campanas las rogativas generales ordinarias de las Cuatro Témporas (celebradas al inicio de las cuatro estaciones del año), y la misa mayor en días de fiesta, pero no las misas conventuales y de alba, celebradas antes.

Hasta nueve testigos llegaron a declarar contra el nuevo uso de las campanas determinado por el intendente, convencidos de que asistían a una flagrante transgresión de los preceptos de la Iglesia, aunque esta denuncia no llegó a tener censura. Y es que el sonido de este instrumento, uno de los más típicos en las sociedades rurales del Antiguo Régimen tanto en España como en las Indias, era imprescindible no solo desde el punto de vista práctico (llamando a la oración, marcando el devenir cotidiano y anunciando eventos ordinarios y extraordinarios por medio de varios toques rigurosamente tipificados), sino también simbólico, pues la poderosa proyección de su sonido suponía una suerte de sacralización inmediata del territorio circundante (Toelle 2016).

El vicario Juan Lanes Duval precisó que, a raíz de un lance entre Olavide y el sacristán de la iglesia de La Carolina, la llave del campanario quedó bajo la custodia del intendente

35 Los instrumentos procedían del convento carmelita de La Peñuela y de las iglesias jesuitas enclaustradas de las Becas de Sevilla y de Santiago y San Ignacio de Baeza. De ellas, dos se instalaron en las iglesias de La Carolina, Carboneros y Guarromán, y una en las de Venta de Linares, Venta de los Santos y Montizón, Aldeaquemada y Mojón Blanco, y Santa Elena; véase Palacios Alcalde 1988: 199.

36 Denuncia de fray Romualdo de Friburgo contra Olavide, La Carolina, 22 de septiembre de 1775, AHN, Inquisición, 1866, exp. 9, sin foliar (imagen digitalizada 9 de Pares).

37 Declaración de Juan Calvet, La Carolina, 8 de abril de 1777, AHN, Inquisición, 1866, exp. 3, fol. $690 \mathrm{r}$. 
y las campanas estuvieron sin tocarse en entierros de la capital foral casi cuatro años (en concreto, entre el 3 de agosto de 1772 y el 3 de abril de 1776) ${ }^{38}$. Otro testigo señaló que, durante una enfermedad temporal de Gracia de Olavide, el intendente decretó una suspensión total del toque durante un mes para no entristecer su ánimo, y solo se anunciaba la misa mayor por medio de una campanilla de mano tocada en las inmediaciones de la parroquia, haciendo que los colonos que vivían más alejados llegasen tarde o, directamente, se quedasen sin misa ${ }^{39}$.

En un amplio memorial privado dirigido a Juan Lanes y destinado a orientar su defensa ante el Santo Oficio, el propio Olavide justificaba su postura, que no consistía en una supresión radical de los toques de campana, sino en una argumentada restricción o cese temporal de su uso por diferentes motivos. En relación con los toques de dobles que tradicionalmente se hacían sonar en entierros, se indicaba que al estar ubicado en La Carolina el Hospital Real y haberse atravesado épocas de alta mortandad (como la epidemia de principios de 1772), el sonido de las campanas podía causar aún más angustia entre los colonos, extender la idea de que el lugar tenía una atmósfera poco saludable o favorecer su deserción; por ese mismo motivo había prohibido que los funerales fuesen cantados y que se procesionase el cadáver en público por las calles, desviando la ruta hacia un olivar cercano ${ }^{40}$. Además, la colocación de unas nuevas campanas de mayor tamaño había provocado cierta inestabilidad en el viejo campanario, por lo que el maestro de obras Juan Bautista Nebroni recomendó tocarlas solo lo imprescindible hasta que estuviese acabada la nueva torre, lo que tomó muchos meses. Finalmente, había una motivación personal: el campanario estaba ubicado justo encima del cuarto de Olavide, quien padecía "mucho terror con los truenos" y había oído decir que el toque de las campanas atraía perpendicularmente los rayos ${ }^{41}$. El testimonio del citado Calvet revela el origen de dicha creencia: en una de las tertulias se leyó un libro del padre Feijoo que trataba el tema de las tempestades (probablemente su Teatro crítico universal) y se concluyó que "el aire atrae los rayos al sonido de las campanas, y que esta es la razón porque los rayos afectan principalmente a las torres y campanarios" 42 .

Vemos que para la abolición de las inmemoriales prácticas asociadas al tañido de las campanas, Olavide mezcló argumentos estrictamente personales con otros ligados a situaciones coyunturales de fuerza mayor y con los propios fundamentos racionales de la física moderna, poniendo siempre por delante el bienestar y seguridad de sus colonos. Sin cuestionar la veracidad real de estos argumentos, como telón de fondo estaba la mente pragmática, realista y desprejuiciada de Olavide; de la muerte ya no sacarían beneficio ni vivos ni muertos, y el hecho de que los agricultores y operarios que levantaban las Nuevas Poblaciones acudiesen a misas, Vísperas de días festivos, entierros y rogativas suponía una pérdida de tiempo para el progreso material de las colonias; al mismo tiempo, tampoco le agradaría - por la mentalidad clasista de la época- encontrar al sacristán transitando por su palacio, ya que el acceso al viejo campanario se hacía por una escalera que estaba en el interior de la residencia.

38 Declaración de Juan Lanes Duval, La Carolina, 2 de abril de 1777, AHN, Inquisición, 1866, exp. 3, fols. $897 \mathrm{v}-898 \mathrm{r}$.

39 Declaración de Antonio Capmany, Madrid, 29 de julio de 1777, AHN, Inquisición, 1866, exp. 3, fol. 822 r.

40 Declaración de Francisco Coba, Málaga, 20 de febrero de 1776, AHN, Inquisición, 1866, exp. 2 , fols. 394v-395r.

41 Carta de Pablo de Olavide, Madrid, 9 de mayo de 1776, AHN, Inquisición 1866, exp. 8, documento 25, fols. 50v-53r.

42 Declaración de Juan Calvet, La Carolina, 8 de abril de 1777, AHN, Inquisición, 1866, exp. 3, fol. $680 \mathrm{r}$. 


\section{Músicas devocionales para la iglesia: los “cánticos espirituales” de don Pablo}

Una de las prácticas más novedosas y peculiares que Olavide instauró en las iglesias de las Nuevas Poblaciones fue la interpretación de dos cantos colectivos en castellano dentro de la misa mayor, un canto inmediatamente después de la consagración y otro después de la comunión. El ortodoxo fray Romualdo criticó, además de su falta de decoro, su ilicitud ceremonial (pues no eran parte del rito oficial de la misa) y la obligación que el intendente imponía a todos los colonos para que participasen en el canto:

A los ritos de la misa [Olavide] mezcla otros porque por un despotismo y fuerza hace cantar dos veces en la misma, después de la consagración y después de la sumpción [sic, i.e. comunión], ciertas cantinelas compuestas por él mismo, y manda que todo el pueblo las cante, lo que se ejecuta con tanto estrépito de diversas voces mal concertadas que se ofenden los oídos, y se quita toda atención y devoción ${ }^{43}$.

De la información aportada en el proceso por otros testigos y por el propio Olavide pueden conocerse detalles muy específicos acerca del origen, desarrollo y acogida de este interesante y desconocido repertorio. Así explicaba el propio intendente el surgimiento de esta práctica:

62. Sucedió también que, una vez entablada la asistencia general a la misa mayor, los alemanes de ambos sexos siguiendo su costumbre y estilo de su país cantaban algunas canciones en su idioma, principalmente después que se elevaba la hostia. Me hice explicar el sentido de estas palabras, que me parecieron devotas. Yo entonces hacía cuanto podía para hacer a los alemanes españoles, induciéndolos a dejar su idioma y que aprendiesen el nuestro.

63. Por otra parte, deseé que el fruto de esta devoción se extendiese a nuestros nacionales, cuyo número era ya mayor en la iglesia. No vi ningún inconveniente, pues todos los días en nuestras ciudades y conventos más devotos se advierte que en las festividades se solemnizan las misas, y que al tiempo que éstas se dicen, se cantan en los mismos intervalos: esto es, después que se eleva y adora al Señor en unas partes oraciones devotas, y en otras cuando hay música de capilla las arias o villancicos que disponen los compositores. Por todas estas razones, me pareció no sería inconveniente sino útil para añadir majestad al culto y fomentar la devoción de todos el poner en español las mismas canciones que cantaban los alemanes y persuadir que las cantasen todos. 64. Propuse esta idea al vicario y la aprobó. En consecuencia yo mismo, aprovechándome de la propia música que los alemanes usaban en las suyas para que les fuera más fácil, formé las canciones que aparecen en la copia que incluyo. El vicario las leyó y explicó en el púlpito. Exhortó a que las cantasen todos. Se hizo que el maestro las enseñase a los niños en la escuela. Que las muchachas y demás gentes que están recogidas en las fábricas las aprendiesen. Las personas de más distinción se aplicaron a lo mismo. Todos nos aplicamos. Y todos fuimos a cantarlas y lo hemos continuado hasta ahora con el mayor respeto y devoción ${ }^{44}$.

El médico Juan Calvet detalló que el origen de estas canciones procedía de unos colonos y colonas alemanas establecidas en aldeas fuera de La Carolina, que en las misas conventuales de sus iglesias cantaban en alemán varias coplas devotas; habiendo llegado noticia de ello al intendente, señaló que "a su imitación dicho don Pablo compuso en español las referidas coplas para que los de la nación española las cantasen, y aprendiesen la

43 Denuncia de fray Romualdo de Friburgo contra Olavide, La Carolina, 22 de septiembre de 1775, AHN, Inquisición, 1866, exp. 9, sin foliar (imagen digitalizada 17 de Pares). La negrita es nuestra.

44 Carta de Manuel Lázaro escrita por orden de Olavide ¿al obispo de Jaén?, s.l., s.f., AHN, Inquisición, 1866, exp. 8, documento 53, fols. 188v-189v. 
lengua las alemanas y las cantasen también en español"45. No se precisa cuándo comenzó esta práctica, que parece retrotraerse al establecimiento mismo de las colonias y que se extendió hasta abril de 1776, según precisó el vicario Lanes ${ }^{46}$. Este mismo testigo señaló que ambas canciones se interpretaban de manera colectiva con el acompañamiento del órgano, y que sus textos fueron impresos para ser repartidos entre los colonos ${ }^{47}$. La conservación de los pliegos impresos nos permite conocer la integridad de los textos de estos cánticos, que llevaban por título Postrados y reverentes y Dios eterno, Dios inmenso ${ }^{48}$.

La incorporación de piezas en castellano dentro de la misa no era totalmente nueva, pues existía desde el siglo XVI una tradición bien establecida en muchas catedrales e iglesias de importancia en donde conjuntos profesionales de músicos, agrupados en las correspondientes capillas, interpretaban villancicos y otros géneros afines en lengua romance durante la misa (Torrente 2007: 138-141) ${ }^{49}$. Lo que sí constituía una novedad en el contexto de los usos musicales de las iglesias peninsulares es que estos cantos fuesen interpretados a coro por los propios feligreses y que fuesen acompañados por el órgano. Se trataba de una práctica protestante impulsada por Lutero desde 1517 y asimilada por las comunidades católicas alemanas como parte imprescindible de su experiencia religiosa en comunidad. Es igualmente destacable la denominación de "cántico espiritual" que figura en los pliegos impresos, lo que permite establecer una hipótesis respecto de su posible relación (como guiño histórico) con el Cántico espiritual de San Juan de la Cruz, quien habitó en el convento carmelita de La Peñuela y gozaba de gran devoción en las colonias, llegando a ser proclamado copatrono de La Real Carolina en 1783, junto con la Inmaculada Concepción (Sánchez-Batalla Martínez 1998-2003, vol. 1: 311)50.

Al igual que fray Romualdo, Francisco Coba, cura de El Rumblar y La Carolina, se quejaba de que el desconcierto causado por "aquella variedad de voces sin venir al caso" le obligaba a interrumpir la celebración de la misa ${ }^{51}$. Por su parte, el director de agricultura Antonio Capmany señaló que en su afán de hacer participar a los colonos en los cánticos (ya fuese con su interpretación o con su mera escucha), el intendente obligaba a que, una vez acabada la misa, todos los feligreses permaneciesen de rodillas hasta que finalizase su interpretación, mandando cerrar las puertas de la iglesia después de la elevación de la hostia para que nadie pudiera salir. Esta situación originó, entre abril y junio de 1775, "varios escándalos y tumulto de gentes", ya que madres de familia, arrieros y forasteros deseaban

45 Declaración de Juan Calvet, La Carolina, 8 de abril de 1777, AHN, Inquisición, 1866, exp. 3, fol. $688 \mathrm{v}$.

46 Declaración de Juan Lanes Duval, La Carolina, 2 de abril de 1777, AHN, Inquisición, 1866, exp. 3, fol. $902 \mathrm{v}$.

47 El tesorero Jerónimo Guillanea señaló que dicha práctica se decía contaba con licencia del Consejo de Castilla; véase declaración de Jerónimo Guillanea, La Carolina, 7 de abril de 1777, AHN, Inquisición, 1866, exp. 3, fol. 674r.

48 Ambos pliegos fueron localizados por Defuorneaux (AHN, Inquisición, 3609), y reproducidos en la versión española de su libro (1965: 266-267) y, más recientemente, por Sánchez-Batalla Martínez 1998-2003, vol. 2: 238-239.

49 Esta práctica también se verifica en las misiones americanas; véase Waisman 2015.

50 Aunque en los manuscritos originales San Juan de la Cruz se refirió a su poema como Canciones entre el alma y el esposo, las ediciones realizadas a partir de 1630 cambiaron esa denominación por la de "cántico espiritual" de ahí que Olavide pudiese conocer la obra sanjuanista ya con ese nombre; de hecho, en la ciudad de Sevilla, donde el intendente residió varios años, se realizó una edición que incluía la nueva nomenclatura de "cánticos"; véase San Juan de la Cruz 1703: 272.

51 Declaración de Francisco Coba, Málaga, 20 de febrero de 1776, AHN, Inquisición, 1866, exp. 2, fol. 398 r. 
abandonar la iglesia por "no ser dichos cánticos de obligación alguna" 52 . La apreciación del clérigo milanés José Estefani, cura de La Carolina entre 1774 y 1776, era distinta; en un raro ejercicio de sinceridad ante el Santo Oficio reconocía que había escrito al canónigo lectoral de la Catedral de Jaén alabando la institución de los cánticos, pues, a su entender, no contenían nada contrario a la religión y no le resultaban indecorosos: "yo quiero decir la verdad, que en dichas canciones no hallaba nada que me fastidiase; antes bien, celebrando la misa me excitaban a mayor devoción y a otros no sé si le habrá sucedido lo mismo"53.

Un aspecto controvertido señalado a propósito de los cantos era la introducción de oraciones no previstas en las rúbricas oficiales del misal. Sobre este punto, el vicario Lanes detallaba que la única novedad consistía en que, acabado el segundo cántico,

Se entonaba el verso Domine, salvum fac regem nostrum Carolum, y respondiendo el coro Et exaudi nos in die quâ invocaverimus te, cantaba la oración Quaesumus omnipotens Deus, ut famulus tuus Carolus Rex noster, qui tuâ miseratione suscepit Regni gubernacula $\mathcal{E}^{2} c$., a las que respondiendo el coro Amen se retiraba todo el mundo ${ }^{54}$.

La clave estaba en el verso Domine, salvum fac regem (Señor, salvad al rey, verso 10 del salmo 19), que tenía claras connotaciones regalistas, pues también se decía durante la comunión de todas las misas celebradas en la capilla del Palacio de Versalles ante el rey de Francia; era, por tanto, un emblema de la monarquía francesa y un guiño a esa nación que Olavide quiso incorporar al ceremonial de las Nuevas Poblaciones. Respecto de Et exaudi nos in die qua invocaverimus te ( $Y$ óyenos en el día en que te invocaremos), continuación del verso anterior, se sabe que circuló de manera independiente como oración bíblica en algunos manuales españoles coetáneos destinados a un uso misional (P.D.J.S.S.C.P. 1792: 163).

En una carta al marqués de Grimaldi, ministro de Estado, fray Romualdo denunció la incorrección de estos cantos por su ideario regalista y propuso su prohibición, que fue ratificada por el obispo de Jaén Antonio Gómez de la Torre tras una visita eclesiástica (Perdices Blas 1992: 66-67). En otra misiva, Olavide instaba a Lanes a reconducir al obispo y persuadirlo para el mantenimiento de los cánticos, pues se trataba de una costumbre útil, devota y ya muy arraigada en las colonias, afirmando con acritud: "Esto ciertamente necesita de remedio porque es una vergüenza eterna para todos. Hubo demasiada y no prudente prisa en suspenderlos. Cuanto más tarden en volver a cantarlos, tanto más difícil ha de ser volver a hacerlo" 55 . Después, y en tono más moderado, escribió al obispo, indicando que los cantos, interpretados con la aprobación del vicario, contenían la esencia de los principales misterios marianos, cristológicos y eucarísticos, y que no había nada de malo en que los colonos pidiesen a Dios por la salud del soberano y la prosperidad de las colonias. Afirmaba que las supuestas presiones sobre los colonos eran falsas, pues "todos las aprendieron voluntarios y las cantaban gustosos". Yapelaba en tono idealizado a la emoción que suponía para él mismo y para numerosos transeúntes que visitaban las colonias ver a un pueblo entero dentro de la iglesia cantando de rodillas:

52 Declaración de Antonio Capmany, Madrid, 29 de julio de 1777, AHN, Inquisición, 1866, exp. 3, fol. $823 \mathrm{r}$.

53 Declaración de José Estefani, Madrid, 23 de septiembre de 1777, AHN, Inquisición, 1866, exp. 3, fols. 992r-v.

54 Declaración de Juan Lanes Duval, La Carolina, 11 de junio de 1776, AHN, Inquisición, 1866, exp. 8, documento 25 , fols. 122 r-v.

55 Carta de Olavide a Duval, s.l., s.f., AHN, Inquisición, 1866, exp. 8, documento 25, fol. 80v. 
Que más de dos mil personas con voces arregladas y sostenidas por el órgano, puestas todas de rodillas y en un modo reverente, se prosternan y adoran al Santísimo Sacramento, imploran la misericordia de Dios por la sangre de Jesucristo y la intercesión de su purísima Madre. Y concluyen con pedir a Dios por la salud del rey, su bienhechor, y por la virtud y prosperidad de las colonias mismas. Es imposible oírlo sin enternecerse ${ }^{56}$.

El mismo Olavide señaló que la entonación de ambos cantos se realizaba con las melodías que entonaban los colonos alemanes, adaptando a esas músicas preexistentes los nuevos textos castellanos que, según parece, eran una traducción suya de los originales en alemán. Y es que la práctica del contrafactum era intensamente utilizada en la Alemania reformada, tanto protestante como católica. De hecho, las melodías de muchos corales protestantes se originaron a partir de cantos gregorianos católicos (y también de canciones profanas) y, a su vez, se mantuvieron en uso en áreas de confesión católica a pesar de su prohibición oficial, evidenciando un proceso de intercambio bidireccional. Ello provocó que en algunas ocasiones la misma melodía, a veces con el mismo texto (si no existía un conflicto doctrinal) fuese interpretada por católicos y protestantes (Oettinger 2001: 89-136). Desde el punto de vista didáctico, el uso de los cánticos congregacionales en castellano resultaba particularmente adecuado en un entorno rural como el de las Nuevas Poblaciones, a causa de la ininteligibilidad del latín para muchos de los colonos, la dificultad intrínseca de ciertas melodías gregorianas y también el deseo de, por un lado, ayudar a que los colonos alemanes aprendiesen la lengua castellana ( $\sin$ por ello renunciar a sus prácticas) y, por otro, implicar a los colonos españoles en este tipo de canto colectivo, favoreciendo así la cohesión identitaria de ambos grupos.

La localización precisa de las melodías con las que se cantaban Postrados y reverentes y Dios eterno, Dios inmenso es tarea casi imposible, pues existen multitud de canciones con música interpretadas en iglesias católicas alemanas cuya estructura estrófica es coincidente con los textos traducidos por Olavide. Ambos se reducen, en esencia, a la alternancia de un estribillo en cuartetas de romance octosilábicas y unas coplas con el mismo patrón métrico. Esta estructura poética tan popular hace que el número de posibles melodías con las que pueden cantarse esos textos sea casi infinito ${ }^{57}$. Es verosímil suponer que la melodía utilizada en estos cantos congregacionales tendría las características propias del canto popular religioso: diseño interválico sencillo, y estructura rítmica repetitiva y apegada a la métrica del texto, elementos todos ellos que facilitaban su memorización e interpretación al unísono, como es típico en el canto colectivo (Manzano 1991). Sin duda, el aspecto más novedoso de esta práctica musical residía en que Olavide, inspirándose en una tradición de origen luterano, se anticipó en casi un siglo a los primeros movimientos de reforma de la música sacra en España, que aspiraban a una participación más activa de los fieles en la liturgia por medio de la interpretación de cantos en lengua vernácula (Virgili Blanquet 2010).

No obstante, estos dos cánticos espirituales no fueron los únicos textos religiosos de Olavide destinados a ser cantados. En 1800 el peruano publicó un volumen titulado Salterio

56 Carta de Manuel Lázaro escrita por orden de Olavide ¿al obispo de Jaén?, s.l., s.f., AHN, Inquisición, 1866, exp. 8, documento 53, fols. 189v-190r.

57 Marín-López 2018: 1527-1528, ofrece una adaptación hipotética de los textos de ambos cánticos a dos melodías que figuran en una colección germana de canciones religiosas, el Sacrae Cordis Deliciae (Colonia: Arnoldi Metternich, 1696) del fraile carmelita Fulgencio de Santa María; los textos de ambas melodías presentan una estructura idéntica a la de los cánticos carolinos, incluyendo la repetición de los dos primeros versos del estribillo -y no del estribillo completo- en la alternancia con las coplas. Agradecemos a Pepe Rey sus comentarios acerca de las posibles melodías del cancionero de Santa María adecuadas a los textos de Olavide. 
español o versión parafrásica de los salmos de David. Como anuncia su título, se trata de una traducción parafraseada de los salmos del salterio en versos endecasílabos, aunque también incluye otros cánticos e himnos litúrgicos con otra versificación. El volumen se inscribe en una antigua y venerada tradición literaria que se remonta a los Padres de la Iglesia y que consistía en traducciones y paráfrasis poéticas del salterio, libro de gran atractivo exegético por la complejidad y diversidad de su interpretación y la belleza de sus imágenes poéticas $^{58}$. Por desgracia, a diferencia de muchas antologías similares publicadas en Alemania o Inglaterra que incorporan la melodía o remiten a una canción conocida para cantar el texto, según vimos antes, como contrafactum (siguiendo la tradicional práctica de "al tono de"), el volumen de Olavide no incluye música ni referencia musical alguna. Tan solo en el prólogo, el peruano señaló que había hecho los versos de la misma medida y las estrofas con el mismo número de versos "porque así será más fácil cantarlas todas con algún cántico apropiado para ellas”. Y añade:

Si se hiciera una composición música que cantara una estrofa, se podían cantar con ella todos los salmos, y sería muy útil que esta canción se hiciese general en la nación, que se enseñase a todos los niños en las escuelas y que los curas contribuyesen a que se propagasen en sus parroquias. De este modo, y antes de dos generaciones, se conseguiría que al auxilio de este canto se extendiese entre todos el gusto de cantar estas canciones sagradas, olvidando, puede ser, tantas otras tan indecentes ([Olavide] 1800: XV-XVI).

Se desconoce si esta antología llegó a utilizarse en las colonias carolinas, pues consta la interpretación de canciones religiosas con glosas no solo dentro de la iglesia sino también en la calle y en domicilios particulares ${ }^{59}$. Sí que sabemos que el libro de Olavide fue reimpreso en varias ocasiones (una de ellas en México, en 1835) y que muchos de sus textos fueron incorporados posteriormente en himnarios evangélicos de amplia circulación en España y en otros países de habla hispana avanzado el siglo XIX. Es el caso, entre otros, de la antología Himnos y cánticos con la música para cantarlos en el culto público y en el doméstico (ed. W. W. Rand, Nueva York, [1877], véase Aguiar Rodríguez 2016: 171-175) y del Himnario evangélico (Valparaíso, 1891) ${ }^{60}$, libros que acreditan que los textos olavidianos fueron musicalizados años después de su publicación, constituyendo una muestra del retorno de la obra del criollo peruano a América. También sabemos que otros textos compuestos por Olavide, las populares coplas al Cristo Nazareno, se cantaban y, de hecho, se han venido interpretando en la procesión del Viernes Santo hasta los años cuarenta del siglo XX en Linares (Jaén), ciudad cercana a La Carolina (Suárez Gallego 1997: 5) ${ }^{61}$. Sería interesante indagar posibles rastros de las melodías con las que se cantaron los textos olavidianos en el repertorio tradicional de las Nuevas Poblaciones.

58 Otras paráfrasis en verso del libro de David que confirman el apogeo de esta tradición en la época de Olavide son Los salmos del Santo Rey David (Madrid, 1799) de Pedro Antonio Pérez de Castro, Los salmos traducidos nuevamente al castellano en verso y prosa (Valencia, 1819) de Tomás González Carvajal o, por citar un ejemplo latinoamericano, el Salterio peruano (Lima, 1833) de José Manuel Valdés.

59 Sirva como ejemplo la narración del colono Jacinto Muñoz, quien relata cómo el día de su santo en 1773 cantaba en la puerta de su casa "el Padre Nuestro y el Ave Maria glosados ofrecidos a las benditas ánimas”; declaración de Jacinto Muñoz, La Carolina, 6 de junio de 1777, AHN, Inquisición, 1866, exp. 3, fol. 808r.

60 Agradecemos a Cristián Guerra su información acerca de la presencia de Olavide en el Himnario porteño. Para profundizar en esta antología, véase Guerra Rojas 2014.

61 Los textos fueron reproducidos por Ramírez 1999: 647-654. Véase también Sena Medina 2018. 


\section{Músicas para el ocio recreativo: los bailes públicos}

La tercera de las actividades musicales impulsadas y reguladas de manera directa por Olavide en las Nuevas Poblaciones, inspirándose de nuevo en las costumbres de los colonos alemanes, fueron los bailes públicos. Dicha actividad era clave en su proyecto ilustrado al tener la consideración de diversión lícita e instructiva que servía de sana recreación y necesario complemento al resto de actividades agrícolas, ganaderas y artesanales desarrolladas en su Nueva Arcadia. En la documentación consultada figura sistemáticamente el término "bailes", pero no queda claro si se refería realmente a baile (en el sentido de una manifestación relacionada con clases y ambientes populares y carente de una estructura coreográfica fija) o, más probablemente, a danza (más vinculada a la nobleza y la burguesía en ascensión, y con una secuencia definida de pasos, como la contradanza y el minueto), lo que requeriría la presencia de maestro de danza (Mera 2008).

Estos bailes se celebraban todos los días festivos (a excepción del tiempo de Cuaresma) entre el día de la patrona, la Inmaculada Concepción, y la festividad del Corpus (o en algunos casos la de San Juan). Dicho período estaba coordinado con el calendario agrícola, pues la temporada de bailes comenzaba en diciembre, cuando la siembra del trigo ya estaba hecha, y se extendía hasta junio, cuando se iniciaba la siega y recolección. Tenían lugar por las tardes, después de la hora de Vísperas, en la plaza de la iglesia o de los Mesones -hoy del ayuntamiento-acondicionada al efecto, pues el intendente mandó construir una gradería de piedra donde se ubicaban las mujeres, mientras que los hombres se sentaban en los bancos que cerraban el cuadrado y configuraban el espacio de baile ${ }^{62}$. Se desconoce qué instrumentos actuaban en estos bailes, aunque por un testimonio del presbítero sueco Carlos Frey, párroco de Carboneros, se sabe que los músicos cobraban de la Real Contaduría ${ }^{63}$. En cuanto al repertorio, otro testigo, Juan Calvet, precisó que se trataba de "bailes en alemán, francés y español" y que duraban hasta el anochecer 64 .

La implantación de los bailes públicos llevó aparejada una prohibición de los bailes celebrados en casas particulares y en el campo, pues los colonos alemanes, muy inclinados al baile, lo practicaban "sin decencia, con un pellejo de vino al lado emborrachándose con riñas" 65 . Asimismo, los colonos españoles se habían aficionado a los juegos de naipes y otros vicios que se iban introduciendo en las colonias (Sánchez-Batalla Martínez 1998-2003, vol. 2: 272). Por tanto, los bailes públicos constituían un momento de diversión y encuentro entre extranjeros y nacionales, y su organización como actividad pública dirigida desde el gobierno civil constituía una garantía de orden.

Desde su inicio, Olavide quiso dotar a los bailes públicos de una dimensión oficial y propagandística, reuniendo en ellos a las autoridades civiles y eclesiásticas y convocando a la mayor concurrencia posible de colonos por intermedio de su ayudante de cámara e intérprete, el tirolés Sebastián Steiner. Así, la actividad no podía dar inicio hasta que llegase el alcalde, que presidía el acto en alternancia con el alguacil mayor, y a ella también acudían los alcaldes pedáneos, el subdelegado Miguel de Ondeano y el vicario Juan Lanes acompañado de los demás capellanes con el fin de legitimar la actividad con su misma presencia.

62 Carta de Manuel Lázaro escrita por orden de Olavide ¿al obispo de Jaén?, s.l., s.f., AHN, Inquisición, 1866, exp. 8, documento 53, fols. 179v-181r.

63 Declaración de Carlos Frey, Madrid, 6 de septiembre de 1776, AHN, Inquisición, 1866, exp. 3, fols. $589 \mathrm{v}-590 \mathrm{r}$.

64 Declaración de Juan Calvet, La Carolina, 8 de abril de 1777, AHN, Inquisición, 1866, exp. 3, fol. $689 \mathrm{r}$.

65 Carta de Manuel Lázaro escrita por orden de Olavide ¿al obispo de Jaén?, s.l., s.f., AHN, Inquisición, 1866, exp. 8, documento 53, fol. 180r. 
Según fray Romualdo, Ondeano obligaba a su mujer y a todas sus criadas a bailar con tal de complacer al intendente, menospreciando la prohibición que el capuchino, confesor suyo, les había dado; Lanes también fue acusado de hacer sacar él mismo los bancos de la iglesia a la plaza y presidir algunos bailes ${ }^{66}$. En estos eventos tampoco faltaba el mismo Olavide, "no solo para añadir pompa al espectáculo, sino para dar sujeción y contribuir a que se entablase con decoro y decencia"67. Asimismo, y para aumentar la participación de los colonos, el intendente ordenó que todas las bodas se celebrasen en domingo o día festivo, quedando obligados los nuevos esposos a participar en el baile público ${ }^{68}$.

Como era de esperar, los bailes públicos despertaron recelos en el moralista fray Romualdo y otros contemporáneos, que condenaron no solo su celebración en los días más sagrados del año y la asistencia de niños, sino las multas de diez reales que Olavide imponía a los alcaldes ausentes (lo que parece que se verificó solamente en un caso), las amenazas de "cárceles y cepos" para aquellos colonos que no asistían y el vestuario de las mujeres, que aparecían sin mantilla (desterrada de las aldeas por Olavide), es decir, con la cabeza y cuello descubiertos y el pelo suelto. El contacto corporal entre los danzantes, acompañado de gestos y miradas, constituían un escándalo y un foco permanente de vicio carnal al hacer bailar a mujeres casadas con otros hombres casados que a veces no tenían buenas relaciones con sus cónyuges. Pero lo que realmente molestaba al capuchino era que Olavide había convencido a los colonos de la superioridad moral de los bailes respecto de cualquier otra acción religiosa voluntaria al "persuadir al pueblo que los bailes públicos, aún en los días más sagrados, eran mejores que cualquiera buena obra de supererogación [...]" y que "los ha canonizado con tanta eficacia que ya se creen obras meritorias, y el vicio se vende con título de virtud" 69 .

Otra de las críticas se dirigía a la manera en que estos bailes eran convocados, con "estrépito de música" cuando aún no habían concluido los oficios religiosos en la iglesia ${ }^{70}$. Este "estrépito de música" no era otra cosa que un catalán con un tamboril y una flauta (una formación típica de los pueblos rurales de misiones, como acreditan -por ejemplolos conocidos mapas del pueblo guaraní de San Juan Bautista de la década de 1750) ${ }^{71}$, al que posteriormente se unió por disposición de Olavide otro catalán con una gaita gallega, que marchaban por las calles anunciando a los lugareños el inicio de la fiesta, práctica

66 Denuncia de fray Romualdo de Friburgo contra Juan Lanes, La Carolina, 28 de diciembre de 1775 y 30 de enero de 1776, AHN, Inquisición, 1866, exp. 2, fols. 238r-v, 247r.

67 Carta de Manuel Lázaro escrita por orden de Olavide ¿al obispo de Jaén?, s.l., s.f., AHN, Inquisición, 1866, exp. 8, documento 53, fol. 181r.

68 Según Sánchez-Batalla Martínez 1998-2003, vol. 2: 275, estos actos también permitían recaudar dinero del colono que se ganaba el derecho de bailar con alguna mujer, y que quedaba a beneficio de la cofradía de Ánimas.

69 Denuncia de fray Romualdo de Friburgo contra Olavide, La Carolina, 22 de septiembre de 1775, AHN, Inquisición, 1866, exp. 9, sin foliar (imágenes digitalizadas 10 y 11 de Pares).

70 Denuncia de fray Romualdo de Friburgo contra Olavide, La Carolina, 22 de septiembre de 1775, AHN, Inquisición, 1866, exp. 9, sin foliar (imagen digitalizada 19 de Pares).

71 Se conservan dos versiones de este mapa, ambas accesibles desde los respectivos portales digitales de las bibliotecas que los custodian: Pueblo de S[a]n Joan B[autis]ta del Rio Uruguay y esplicacion de su contenido (1753?), Archivo General de Simancas, Secretaría de Estado, 07381-71 (http://www.mcu.es/ ccbae/es/consulta/registro.cmd?id=176661); y Pueblo de San Juan que e[s] uno de los del Uruguay que se intentan entregar a Portugal (1756), París Bibliothèque Nationale de France, Département Cartes et plans, GE C-2769 (RES), (https://gallica.bnf.fr/ark:/12148/btv1b550047858?rk=21459;2). Agradecemos a Egberto Bermúdez el haber traído a nuestra atención la existencia de estos planos. 
que se verificó hasta $1776^{72}$. Se entiende así que a inicios de 1777 un grupo de colonos catalanes reclamase la vuelta de Olavide, dando como principal argumento que "después de los piadosos ejercicios en los días festivos, les procuraba la diversión del baile, a uso de Cataluña" (Sánchez-Batalla Martínez 1998-2003, vol. 2: 447). Pero para entonces la suerte del intendente estaba a punto de cambiar para siempre.

\section{CONCLUSIONES}

De lo expuesto en este estudio se puede inferir que, si bien Olavide no recibió una formación musical profesional (hasta donde tenemos constancia), la música estuvo presente durante toda su vida tanto a nivel personal como en su acción de gobierno, ya fuera como protector del teatro lírico, impulsor de una enseñanza pública para las élites con presencia de la música, promotor de la práctica musical en las tertulias que instituyó allá donde tuvo residencia estable (y a las que asistían melómanos invitados), y su condición misma de cantante e intérprete de teclado. Todo ello está en plena consonancia con su sólida formación humanista, literaria y artística, adquirida en distintos países y por una gran biblioteca. Estamos, por tanto, ante un perfil inédito de este intelectual cosmopolita, que demuestra aún con mayor claridad su plena inserción en las coordenadas culturales de la Ilustración europea.

El pensamiento musical de Olavide se vio claramente reflejado en la vida cotidiana de las Nuevas Poblaciones durante su primera década de vida. En consonancia con los principios ideológicos del utilitarismo, Olavide concibió un paisaje sonoro de características del todo inusuales en la España de la época, y también del todo apropiado -a su juicio- para la reformada sociedad agraria que imaginó en Sierra Morena. Solo una organización musical basada en reglas sencillas y racionales contribuiría al progreso material y espiritual de las colonias, lo que pasaba por un uso justificado de las campanas -tendente a reducir su presencia en el paisaje sonoro de las aldeas-, la supresión de prácticas para él supersticiosas y oscurantistas como el canto del rosario, la introducción de un canto eclesiástico congregacional de raíz popular -en castellano pero deudor de una práctica que enraizaba con la tradición musical importada por los colonos- y la instauración de bailes públicos para los ratos de ocio y diversión de los colonos, algo que el Estado debía asumir como una obligación. Esta batería de actuaciones en materia musical fue posible gracias a la idiosincrasia cultural de los nuevos moradores y la dinámica y modernista personalidad del plenipotenciario intendente. Su avanzado pensamiento musical revela, por tanto, el mismo espíritu reformista y antiescolástico que se aprecia en sus escritos referidos al teatro, la agricultura, la educación o el comercio. Además, su implementación durante los difíciles inicios del proyecto colonizador no hubiera sido posible sin el especial régimen de gobierno que posibilitó el Fuero, y que concedió al intendente un amplio margen de actuación en las aldeas bajo su jurisdicción.

Futuros trabajos deberán profundizar en la difusión de estas prácticas en el resto de feligresías y aldeas de las Nuevas Poblaciones, así como en la recepción que hicieron de este legado musical los sucesores de Olavide, aunque es posible pensar -en virtud de la severa condena recibida- que abandonarían el programa reformista ideado por el peruano. Ello no implicaría que la música desapareciese de las colonias ni que perdiese su función

72 Declaración de Juan Lanes Duval, La Carolina, 2 de abril de 1777, AHN, Inquisición, 1866, exp. 3, fol. 902v; y declaración de Jerónimo Guillanea, La Carolina, 7 de abril de 1777, mismo expediente, fol. 675r. Acerca de la presencia de catalanes en las colonias carolinas, véase Hamer Flores 2005. 
representativa y articuladora en la nueva sociedad, sino más bien que adquiriese otras características y se asemejase cada vez más a las prácticas musicales de otras villas y ciudades.

Con sus luces y sus sombras, lo cierto es que la floreciente labor de Olavide al frente de las Nuevas Poblaciones de Andalucía y Sierra Morena marcó una época y se hizo famosa en toda España, convirtiéndose en emblema del progreso ilustrado. Ello se reflejó incluso en el teatro musical de la época al que tan aficionado era el intendente. En la tonadilla a solo La España moderna de Blas de Laserna, estrenada en Madrid en 1785, el personaje que representa a La España moderna va repasando los adelantos materiales, técnicos y artísticos del tiempo presente, e indica que "Sierra Morena, sobre esto / autoriza mi opinión"73. No son las únicas tonadillas que incluyen alusiones a las Nuevas Poblaciones, sin duda el gran proyecto de vida del afrancesado, ilustrado y desde ahora músico Pablo de Olavide y Jáuregui.

\section{BIBLIOGRAFÍA}

AA.VV

1992 Madame Du Barry: de Versailles à Louveciennes. París: Flammarion.

Aguiar Rodríguez, Josué

2016 "Suenen dulces himnos: orígenes de los himnarios evangélicos en España (fijación del corpus)". Tesis para la obtención del Grado de Doctor. Las Palmas: Universidad de Las Palmas de Gran Canaria. Profesor guía: José Ismael Gutiérrez Gutiérrez.

Aguilar Piñal, Francisco

1974 Sevilla y el teatro en el siglo XVIII. Oviedo: Universidad de Oviedo.

1989 Pablo de Olavide. Plan de estudios para la Universidad de Sevilla. Sevilla: Universidad de Sevilla.

Alcázar de Molina, Cayetano

1929 Los hombres del reinado de Carlos III. Don Pablo de Olavide, el colonizador de Sierra Morena. Madrid: Voluntad.

Alonso Herreros, Gonzalo J.

2013 "VI Conde de Fernán-Núnez", Sones de ida y vuelta: músicas coloniales (1492-1898). [Libro del] XIII Festival de Música Antigua de Úbeda y Baeza. Editado por Javier Marín-López y Virginia Sánchez-López. Baeza: Festival de Música Antigua de Úbeda y Baeza, pp. 36-37.

ANDRÉs-Fernández, DAVID

2017 "Canto, liturgia, ceremonial y culto en América Latina según la Recopilación de Leyes de los Reynos de Indias", Resonancias, 21/40 (enero-junio), pp. 13-32. DOI: https://doi. org/10.7764/res.2017.40.2

BAGÜÉs ERriondo, JoN

1990 Ilustración musical en el País Vasco. Vol. 1: La música en la Real Sociedad Bascongada de los Amigos del País. Donostia-San Sebastián: R.S.B.A.P.

Calderón España, María Consolación

1991 "La Sociedad Económica Sevillana de Amigos del País: una institución clave para la educación en Sevilla (1775-1900)". Tesis para la obtención del Grado de Doctor. Sevilla: Universidad de Sevilla, 2 vols. Profesora guía: María Isabel Corts Giner.

73 Véase el texto completo en Fundación Juan March 2016: 32-33, así como su grabación en video en el canal Youtube de la institución (https://www.youtube.com/watch?v=iAf09_u5qXk [acceso: 19 de noviembre, 2020]; la sección cantada con la referencia a Sierra Morena comienza en 52:15). 


\section{Calderone, Antonietta}

1987 "Le Déseteur, dalla traduzione di Pablo de Olavide alla rielaborazione di J. López Sedano", Letterature, 10, pp. 7-48.

Calzavara, Alberto

1987 Historia de la música en Venezuela. Período hispánico (con referencias al teatro y la danza). Caracas: Fundación Pampero.

Capel Margarito, Manuel

1970 La Carolina, capital de las Nuevas Poblaciones (Un ensayo de reforma socio-económica de España en el siglo XVIII). Jaén: Instituto de Estudios Giennenses.

1997 Don Pablo de Olavide, un criollo en el equipo reformista de Carlos III. Jaén: el autor.

Caso González, José

1961 Poesías. Gaspar Melchor de Jovellanos. Oviedo: Instituto de Estudios Asturianos.

Castañeda, Vicente

1916 "Relación del auto de fe en el que se condenó a D. Pablo de Olavide", Revista de archivos, bibliotecas y museos, 25, pp. 93-111.

Crèvecoeur, RoBerT DE

1909 Mémoires du comte Dufort de Cheverny. París: Librarie Plon, 2 vols.

Defourneaux, Marceline

1959 Pablo de Olavide ou l’Afrancesado (1725-1803). París: Presses Universitaires de France, 1959. Ed. española: México D.F.: Editorial Renacimiento, 1965.

Dufour, GÉRARD

1997 Pablo de Olavide. Cartas de Mariano a Antonio. El programa ilustrado de "El evangelio en triunfo". Aix-en-Provence: Université de Provence.

Estenssoro, Juan Carlos

1989 Música y sociedad coloniales: Lima 1680-1830. Lima: Colmillo Blanco.

Fundación JuAn March

2016 Trilogía de Tonadillas. Blas de Laserna. Teatro musical de Cámara (4). Madrid: Fundación Juan March, disponible en https://recursos.march.es/culturales/documentos/conciertos/ co100523.pdf?v=96528577 [acceso: 29 de diciembre, 2017].

Gallego, Antonio

1988 La música en tiempos de Carlos III. Madrid: Alianza.

Gómez URDÁñez, José Luis

2015 "Con la venia de Carlos III. El castigo "ejemplar" de Olavide, consecuencia de la venganza de Grimaldi contra el conde de Aranda”, Vegueta: Anuario de la Facultad de Geografía e Historia, 15 , pp. 373-400.

GonzÁlez de León, Antonio

1768 El hijo de Ulises. Sevilla: Imprenta de Manuel Nicolás Vázquez. Universidad de Sevilla, Fondo Antiguo, H 8/00694, digitalizado en: http:/ /fondosdigitales.us.es/fondos/libros/4699/36/ el-hijo-de-ulises-zarzuela-escrita-por-don-antonio-gonzalez-de-leon-de-la-real-academia-debuenas-letras-de-esta-ciudad/ [acceso: 8 de enero, 2018].

Guerra Rojas, Cristián

2014 "El Himnario Evangélico de 1891: primer himnario protestante con música impreso en Chile", Resonancias, 18/35 (julio-noviembre), pp. 101-132. DOI: 10.7764/res.2014.35.7

Hamer Flores, Adolfo

2005 "Catalanes y valencianos en la Andalucía del siglo XVIII: las Nuevas Poblaciones de Carlos III", Ámbitos. Revista de Estudios de Ciencias Sociales y Humanidades, 14, pp. 43-51. 
Heartz, Daniel

2003 Music in European Capitals: The Galant Style, 1720-1780. Nueva York: W. W. Norton.

Jiménez Cavallé, Pedro

1991 La música en Jaén. Jaén: Diputación Provincial de Jaén.

Lavalle, José Antonio de

1885 Don Pablo de Olavide (apuntes sobre su vida y sus obras), $2^{\mathrm{a}}$ ed. aumentada. Lima: Imprenta del Teatro.

Leza, José Máximo (ED.)

2014 Historia de la música en España e Hispanoamérica. Vol. 4. La música en el siglo XVIII. Madrid: Fondo de Cultura Económica.

Lohmann Villena, Guillermo

1945 El arte dramático en Lima durante el Virreinato. Madrid: Escuela de Estudios Hispano-Americanos de la Universidad de Sevilla.

1964 Pedro de Peralta. Pablo de Olavide. Lima: Editorial Universitaria.

Manzano, Miguel

1991 "El canto popular religioso en la tradición oral", ponencia en Jornadas "La música en la Iglesia, de ayer a hoy", León, 5-7 de septiembre de 1991, disponible en http://www. miguelmanzano.com/pdf/EL\%20_CANTO\%20_POPULAR\%20_RELIGIOSO\%20_ EN\%20_LA\%20_TRADICION_ORAL.pdf [acceso: 18 de diciembre, 2017].

MARChENA, JUAN

2001 El tiempo ilustrado de Pablo de Olavide: vida, obra y sueños de un americano en la España del s. XVIII. Sevilla: Ediciones Alfar.

MARÍN-López, JAVIER

2007 "Un tesoro musical inexplorado: los libros de polifonía de la Catedral de Baeza", Estudios de Humanismo Español. Baeza en los siglos XVI y XVII. Editado por María Águeda Moreno Moreno. Baeza: Ayuntamiento de Baeza, pp. 319-346.

2017 "Música, nobleza y vida cotidiana en la Hispanoamérica del siglo XVIII: hacia un replanteamiento", Acta Musicologica, 89/2, pp. 123-144.

2018 "Cultura musical y Nuevas Poblaciones", [Actas del] Congreso Internacional "Nuevas Poblaciones de Sierra Morena y Andalucía y otras colonizaciones agrarias en la Europa de la Ilustración”, 2 vols. Editado por Adela Tarifa Fernández, José Antonio Fílter Rodríguez y Amparo Ruiz Olivares. Jaén: Instituto de Estudios Giennenses. Vol. 2, pp. 1513-1537.

Martín Moreno, Antonio

1985 Historia de la música española. 4. El siglo XVIII. Madrid: Alianza.

Mera, Guadalupe

2008 "La danza, el baile, los saraos, la danza escénica y los bailes populares. Notas y precisiones sobre su estado en la España ilustrada”. Editado por Joaquín Álvarez Barrientos y Begoña Lolo. Teatro y música en España: los géneros breves en la segunda mitad del siglo XVIII. Madrid: Universidad Autónoma de Madrid y Consejo Superior de Investigaciones Científicas, pp. $459-480$.

Moreno Mengíbar, Andrés

1998 La ópera en Sevilla en el siglo XIX. Sevilla: Universidad de Sevilla.

Moreno Yáñez, Segundo y Christiana Borchart de Moreno (eds.)

2005 Alexander von Humboldt: diarios de viaje en la Audiencia de Quito. Quito: Occidental Exploration and Production Company.

NúÑez, EstuARdo

1971 Pablo de Olavide. Obras dramáticas desconocidas. Lima: Biblioteca Nacional del Perú, disponible en la edición digital de la Biblioteca Virtual Miguel de Cervantes: http://www. 
cervantesvirtual.com/obra-visor/obras-dramaticas-desconocidas-el-zeloso-burlado-la-fedra/ html/ff375de2-82b1-11df-acc7-002185ce6064_3.html\#I_2_[acceso: 30 de diciembre, 2017].

1987

Pablo de Olavide. Obras selectas. Lima: Banco Nacional del Perú.

Oettinger, Rebecca Wagner

2001 Music as Propaganda in the German Reformation. Aldershot: Ashgate.

[Olavide, Pablo DE]

1797-1798 El Evangelio en triunfo o Historia de un filósofo desengañado. Valencia: Hermanos de Orga.

1800 Salterio Español o versión parafrástica de los salmos de David, de los Cánticos de Moisés, de otros Cánticos, y algunas oraciones de la Iglesia en verso castellano, a fin que se puedan cantar para uso de los que no saben latín. Madrid: José Doblado.

Palacios Alcalde, María

1988 "Mobiliario litúrgico distribuido a las iglesias de las Nuevas Poblaciones de Sierra Morena". Carlos III y las "Nuevas Poblaciones", 3 vols. Editado por Miguel Avilés Fernández y Guillermo Sena Medina, Córdoba: Universidad de Córdoba y Cajasur, vol. 3, pp. 189-214.

P.D.J.S.S.C.P.

1792 Introducción reverente a las sagradas misiones, a fin de que las gentes más ocupadas dejen de sacar frutos dignos de penitencia en el santo tiempo de Cuaresma, y hacer buena confesión y digna comunión [...] dedica de los mejores ascéticos por el P. D. J. S. S. C. P. [José Santos] Madrid: Blas Román.

Perdices Blas, Luis

1992 Pablo de Olavide (1725-1803), el ilustrado. Madrid: Editorial Complutense.

2003 "Pablo de Olavide (1725-1803) a través de sus escritos", Cuadernos Dieciochistas, 4, pp. 13-30.

Pérez Fernández, Francisco Javier

2016 "Algunas notas sobre la música culta en las Nuevas Poblaciones de Sierra Morena", Boletín del Centro de Estudios Neopoblacionales, 9 y 10 (agosto-diciembre), pp. 35-52.

RAMírez, FEDERICO

1999 Linares: documentos y apuntes de tiempos antiguos, estudio preliminar y notas por Juan Sánchez Caballero y Félix López Gallego. Jaén: Diputación Provincial de Jaén, Área de Cultura y Deportes.

Rodríguez-MoÑino, RAFAEL

1994 Don Pablo de Olavide y la ciudad de Baeza. $2^{\text {a }}$ ed. ampliada. La Carolina: Cuadernos del Seminario de Estudios Carolinenses.

SAN JuAn de la Gruz

1703 Obras espirituales que encaminan a una alma a la más perfecta unión con Dios en transformación de amor, por el extático y sublime doctor místico, el beato padre San Juan de la Cruz, primer padre de la Reforma. Sevilla: Francisco de Leefdael.

Sánchez-Batalla Martínez, Carlos

1998-2003 La Carolina en el entorno de sus colonias gemelas y antiguas poblaciones de Sierra Morena. [Jaén]: Caja Rural de Jaén, Servicio de Publicaciones, 4 vols.

Sanhuesa Fonseca, María

2013 "Junta pública y función con pompa: la capilla musical de la Catedral de Oviedo en la Real Sociedad Económica de Amigos del País de Asturias”, Musicología global, musicología local. Editado por Javier Marín-López, Germán Gan Quesada, Elena Torres Clemente y Pilar Ramos López. Madrid: Sociedad Española de Musicología, pp. 1101-1120.

Santiago Medina, Bárbara

2016 "La burocracia inquisitorial: escrituras y documentos". Tesis para la obtención del Grado de Doctor. Madrid: Universidad Complutense. Profesor guía: Juan Carlos Galende Díaz. 
Sena Medina, Guillermo

2018 "El poeta Pablo de Olavide", [Actas del] Congreso Internacional "Nuevas Poblaciones de Sierra Morena y Andalucía y otras colonizaciones agrarias en la Europa de la Ilustración”, 2 vols. Editado por Adela Tarifa Fernández, José Antonio Fílter Rodríguez y Amparo Ruiz Olivares. Jaén: Instituto de Estudios Giennenses. Vol. 2, pp. 1263-1290.

Stevenson, Robert

1976 La Púrpura de la Rosa. Estudio preliminar y transcripción. Lima: Instituto Nacional de Cultura.

Suárez Gallego, José María

1988 Colonos, vecinos y forasteros de la Real Población del Sitio de Guarromán (1767-1781). Guarromán: Ayuntamiento de Guarromán.

1997 Las "Coplas del Calvario" de Pablo de Olavide y los pregones del Viernes Santo. La Carolina: Centro de Estudios sobre Nuevas Poblaciones "Miguel Avilés".

Subirá, José

1928-1930 La tonadilla escénica. Madrid: Tipografía de Archivos, 3 vols.

Toelle, JutTA

2016 "Todas las naciones han de oyrla: Bells in the Jesuit reducciones of Early Modern Paraguay", Journal of Jesuit Studies, 3/3, pp. 437-450. doi: https://doi.org/10.1163/22141332-00303005

TORRente, Álvaro

2007 "Function and liturgical context of the villancico in Salamanca Cathedral", Devotional Music in the Iberian World, 1450-1800. The Villancico and Related Genres. Editado por Tess Knighton y Álvaro Torrente. Aldershot: Ashgate, pp. 99-147.

Vera, Alejandro

2018 "De modernas oberturas para orquesta y antiguos minuetos para guitarra: nuevas luces sobre la recepción de la música instrumental europea en Lima a finales del siglo XVIII”, Músicas coloniales a debate. Procesos de intercambio euroamericanos. Editado por Javier Marín-López. Madrid: Instituto Complutense de Ciencias Musicales, pp. 283-309.

Virgili Blanguet, María Antonia

2010 "El canto popular religioso y la reforma litúrgica en España (1850-1915)", Aisthesis. Revista Chilena de Investigaciones Estéticas, 47 (julio), pp. 175-186. doi: http://dx.doi.org/10.4067/ S0718-71812010000100012

WAISMAN, LEONARDO

2015 Un ciclo musical para la vida en las misiones jesuíticas: los cuadernillos de ofertorios de San Rafael (s. XVIII). 3 vols. Córdoba: Editorial Brujas.

\section{Fuentes manuscritas}

Madrid, Archivo Histórico Nacional, Inquisición, 1866, expedientes 1-10.

Madrid, Archivo Histórico Nacional, Inquisición, 3609.

Madrid, Biblioteca Histórica Municipal, Mus 67-39.

Madrid, Biblioteca Histórica Municipal, Mus 128-10.

Madrid, Universidad Complutense, Biblioteca Histórica, BH FLL 29265(3).

Sevilla, Archivo General de Indias, Contratación, 5524.

Sevilla, Universidad de Sevilla, Fondo Antiguo, H 8/00694. 